\title{
TAZKIYAT AL-NAFS: \\ KAJIAN TENTANG TAZKIYAT AL-NAFS \\ SEBAGAI PENDEKATAN DIRI KEPADA ALLAH
}

\author{
Ahmad Asmuni \\ IAIN Syekh Nurjati Cirebon
}

\begin{abstract}
Abstrak: Jiwa yang dalam bahasa Arab dikenal dengan istilah nafs. Nafs merupakan bagian yang sangat penting dalam diri manusia. Apabila nafs manusia bersih maka ia bisa dekat dengan tuhannya. Sebaliknya apabila nafs manusia kotor maka manusia akan jauh dari tuhannya. Saat nafs manusia kotor maka saat itulah komunikasi manusia dengan tuhan terasa sulit. Pada ssat demikian, maka manusia perlu membersihkan nafs-nya. Pembersihan jiwa manusia dalam dunia tasawuf dikenal dengan istilah tazkiyat al-nafs. Tazkiyat nafs ini sangat penting untuk dilakukan oleh manusia agar jiwanya menjadi bersih dan bisa dekat sedekat-dekatnya dengan tuhannya. Pada saat nafs manusia bersih maka terbukalah semua hijab yang menutupi antara dirinya dengan tuhannya. Ketika semua hijab terbuka maka tak ada lagi penghalang yang dapat menutupi penglihatan mata hatinya terhadap tuhan.
\end{abstract}

Kata Kunci: Nafs, Roh dan Tazkiyat Al-Nafs

\section{A. PENDAHULUAN}

Kesibukan manusia dengan masalah kehidupannya tanpa terasa telah menjadikannya semakin jauh dari tuhannya. Jauhnya manusia dari tuhannya membuat jiwanya tidak renteram. Karena jiwanya tidak tentram maka hidupnya-pun menjadi tdak tentram dan tidak teratur. Jiwanya yang selalu diliputi dengan persoalan-persoakan duniawi membuat jiwanya menjadi semakin terhijab dan jarak dengan tuhannya menjadi semakin jauh.

Untuk kembali dekat dengan tuhannya maka diperlukan untuk mem-bersihkan dirinya dengan cara membersihkan jiwanya (nafsnya). Pembersihan jiwa dalam istilah tasawuf dikenal dengan istilah tazkiyat al-Nafs. Dengan tazkiyat al-Nafs maka jiwa manusia akan kembali menjadi bersih dan dengan jiwa yang bersih, maka manusia dapat kembali dekat sedekat-dekatnya dengan tuhan. Dengan posisi 
jiwa manusia yang dekat dengan tuhannya, maka hidup manusia akan dipenuhi dengan cahaya tuhan (nur tuhan. Dengan nur tuhan, maka hidup manusia akan menjadi tentram dan bahagia.baik ketika dia hidup di dunia maupun saat di akherat kelak. Dengan demikian jelas bahwa tazkiyat al-Nafs ini sangat penting untuk dilakukan oleh manusia larena dengan melakukan tazkiyat al-nafs, jiwa manusia menjadi bersih dan bersinar karena mendapat pancaran sinar dari Allah swt tuhan sang pemilik sinar, yang akan menyinari jiwa siapapun yang dikehendaki-Nya.

B. TAZKIYAT AL-NAFS

\section{Pengertian Al-Nafs (Jiwa) Prespektif Tasawuf}

Istilah Al-Nafs banyak mendapat perhatian dari para pakar dan pemikir. Istilah al-nafs selalu menarik untuk dibahas baik dalam ruang seminar maupun dalam ruang perkuliahan bahkan di ruang terbuka yakni ruang kehidupan manusia yang tanpa dibatasi oleh dinding-dinding.

Al-nafs di kalangan ahli tasawuf, diartikan sesuatu yang melahirkan sifat tercela. Al Ghazali misalnya menyebut nafs sebagai pusat potensi marah dan syahwat pada manusia serta sebagai pangkal dari segala sifat tercela. ${ }^{1}$

\section{Pengertian Al-Nafs (Jiwa) Prespektif Filsafat}

Pengertian jiwa dalam filsafat, diklasifikasikan dengan bermacam-macam makna, antara lain:

a. Jiwa merupakan substansi yang berjenis khusus, yang dilawankan dengan substansi materi, sehingga manusia dipandang memiliki jiwa dan raga.

b. Jiwa merupakan suatu jenis kemampuan, yakni semacam pelaku atau pengaruh dalam berbagai kegiatan.

c. Jiwa adalah sebagai jenis proses yang tampak pada organismeorganisme hidup.

1 Al-Ghazali. Abu Hamid. Fatihat Al-Ulum. Al-qahirat : MathbathShubaihi. 1963., hlm., : 1345. Dalam. Noer Rohmah. Pengantar Psikologi Agama. Yogyakarta; Teras. 2013., hlm., 306 
d. Ada yang menyamakan pengertian jiwa dengan pengertian tingkah laku. ${ }^{2}$

\section{Pengertian Al-Nafs (Jiwa) Prespektif Psikologi}

Jiwa dalam konteks psikologi, lebih dihubungkan dengan tingkah laku, sehingga yang dimaksud ilmu jiwa adalah ilmu tentang tingkah laku. Karena suatu ilmu itu harus logis dan empiris, sedangkan jiwa itu sendiri tidak dapat diselidiki secara empiris maka dari itu yang diselidiki dalam psikologi adalah perbuatan-perbuatan yang dipandang sebagai gejala-gejala dari jiwa, atau tingkah laku manusia itu telah menggambarkan sisi kejiwaannya.

Teori-teori psikologi, baik Psikoanalisa (yang menempatkan keinginan bawah sadar sebagai penggerak tingkah laku), teori Behaviorisme (yang menempatkan manusia sebagai makhluk yang tidak berdaya menghadapi ling-kungan sebagai stimulus), maupun teori Humanisme (yang memandang manusia sebagai makhluk yang memiliki kemauan baik dalam merespon lingkungan), semua memandang jiwa sebagai sesuatu yang berada di belakang tingkah laku. $^{3}$

\section{Pengertian Al-Nafs (Jiwa) Prespektif Al-Quran}

Kata "Jiwa" dalam al-Qur'an diwakili dengan kata "Nafs". Meskipun makna "nafs" ini secara umum bisa diartikan sebagai "diri ". Penggunaan kata "nafs " yang berarti "jiwa " difirmankan Allah dalam al -Qur'an tidak kurang dari 31 kali, sedangkan kata "nafs" (anfus) yang bermakna "diri" telah di-firmankan tidak kurang dari 279 kali dalam al-Qur'an. ${ }^{4}$

Berikut ini beberapa ayat dari al-Qur'an yang menggambarkan tentang pengertian "jiwa ", antara lain yaitu: QS. Az Zumar: 42

\footnotetext{
${ }^{2}$ Noer Rohmah. Pengantar Psikologi Agama. Ibid., hlm., 305

3 Hasan Langgulung, Manusia dan Pendidikan., Jakarta : Al-Husna., 1983., hlm., 26.

${ }^{4}$ M. Yudhie Haryono (Ed). Al-Quran Kritis. Jakarta : Nalar Bekerjasama dengan PT. Inti Media Cipta Nusantara. 2003., hlm., 307
} 


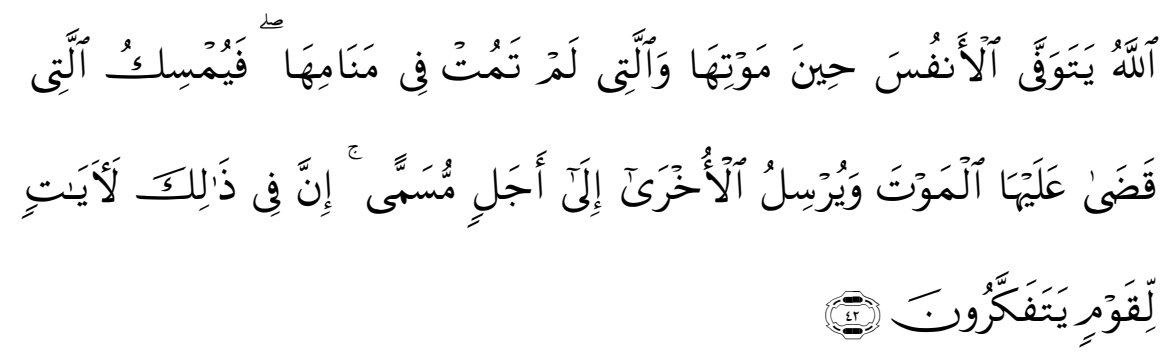

Artinya: Allah memegang jiwa (orang) ketika matinya dan (memegang) jiwa (orang) yang belum mati di waktu tidurnya; Maka dia tahanlah jiwa (orang) yang Telah dia tetapkan kematiannya dan dia melepaskan jiwa yang lain sampai waktu yang ditetapkan. ${ }^{5}$ Sesungguhnya pada yang demikian itu terdapat tanda-tanda kekuasaan Allah bagi kaum yang berfikir. ${ }^{6}$

Ayat di atas menjelaskan bahwa; orang-orang yang mati itu rohnya ditahan Allah sehingga tidak dapat kembali kepada tubuhnya; dan orang-orang yang tidak mati hanya tidur saja, rohnya dilepaskan sehingga dapat kembali kepadanya lagi. Dari ayat ini memberikan pengertian kepada kita semua bahwa "jiwa " dipersamakan dengan "roh".

Selanjutnya dalam ayat lain yakni Qs. Yusuf: 22 Allah berfirman

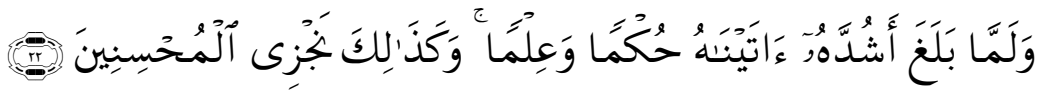

Artinya: Dan tatkala dia cukup dewasa, ${ }^{7}$ kami berikan kepadanya hikmah dan ilmu. Demikianlah kami memberi balasan kepada orang-orang yang berbuat baik. ${ }^{8}$

Ayat di atas menjelaskan bahwa jiwa adalah "sesuatu" yang ada dalam diri kita, yang memiliki kemampuan semakin tinggi dalam menangkap ilmu dan hikmah. Dia bisa memahami makna yang tersimpan di dalam suatu informasi. Bahkan dia juga bisa

\footnotetext{
${ }^{5}$ Maksudnya: orang-orang yang mati itu rohnya ditahan Allah sehingga tidak dapat kembali kepada tubuhnya; dan orang-orang yang tidak mati Hanya tidur saja, rohnya dilepaskan sehingga dapat kembali kepadanya lagi.

${ }^{6}$ QS. Az Zumar: 42

${ }^{7}$ Nabi Yusuf mencapai umur antara 30 - 40 tahun.

${ }^{8}$ Qs. Yusuf: 22
} 
melakukan analisa dan mengambil keputusan dalam menyerap ilmu dan hikmah tersebut. Hal seperti ini terutama akan terjadi pada mereka yang mau memproses pengalaman jiwanya ke arah yang baik dan positif. ${ }^{9}$

Terkait dengan masalah ruh atau jiwa Allahpun berfirman dalam Al-Quran surat Asy Syam : 7-10 berikut ini:

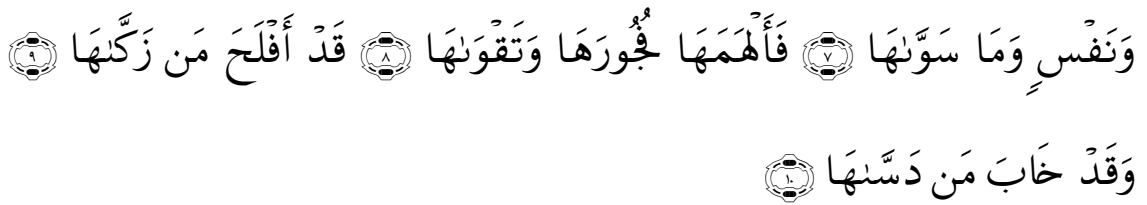

Artinya: Dan jiwa serta penyempurnaannya (ciptaannya), Maka Allah mengilhamkan kepada jiwa itu (jalan) kefasikan dan ketakwaannya. Sesungguhnya beruntunglah orang yang mensucikan jiwa itu, Dan Sesungguhnya merugilah orang yang mengotorinya. ${ }^{10}$

Firman Allah swt di atas, menjelaskan kepada kita semua bahwa jiwa itu akan mengalami penyempumaan pada usia dewasa setelah melewati proses kehidupan, pengalaman, dan pembelajaran. Dan dalam proses penyempumaan itu jiwa bisa mengarah kepada kebaikan, atau sebaliknya pada keburukan. Semua itu tergantung pada manusia itu sendiri, apakah dia berusaha mengisi jiwanya dengan selalu berbuat kebaikan, atau justru manusia itu sendiri yang selalu mengotori jiwanya dengan melakukan hal-hal yang dilarang oleh agama.

Jika manusia selalu berusaha membersihkan jiwanya, maka beruntung-lah manusia itu. Karena jiwa yang bersih akan memberikan manfaat yang besar bagi hidupnya baik di dunia maupun di akhirat kelak. Begitu pula sebaliknya bila ia selalu mengotori jiwanya dengan perbuatan-perbuatan maksiat maka ia akan merugi, karena jiwa yang kotor itu akan memunculkan berbagai masalah dan penderitaan sepanjang hidupnya di dunia dan

${ }^{9}$ Noer Rohmah. Pengantar Psikologi Agama., op., cit Yogyakarta; Teras. 2013., hlm., 308.

${ }^{10}$ QS. Asy Syam : 7-10 
diakhirat kelak ia akan menghadapi siksaan yang amat berat dari Tuhan. ${ }^{11}$

Selain itu, Allahpun berfirman dalam Kitab Suci al-Quran;

Artinya: "Maka berjalanlah keduanya; hingga tatkala keduanya berjumpa dengan seorang anak, Maka Khidhr membiinuhnya. Musa berkata: "Mengapa kamu membunuh jiwa yang bersih, bukan karena Dia membunuh orang lain? Sesung-guhnya kamu telah melakukan suatu yang mungkar".

Dari dialog antara Nabi Musa dengan Nabi Khidir tersebut, memberi-kan petunjuk pada kita bahwa jiwa pada asalnya adalah suatu potensi yang bersih/suci. Sehingga Rasululahpun mengatakan dalam sunnahnya bahwa orang tuanyalah yang menjadikannya Yahudi, Nasrani atau Majusi.

$$
\text { كل مولود يولد على الفطرة فأبو اه يهودانه أوينصر انه أويمجسانه }
$$

Artinya: Setiap anak yang lahir dalam keadaan fitrah. Maka kedua orangtuanyalah yang akanmembuatnya menjadi Yahudi, Nasrani ataupu Majusi. ${ }^{12}$

Maka dari itu jiwa yang merupakan potensi yang memiliki kecenderungan untuk melakukan kebaikan akan tidak bisa aktual manakala orang tua atau lingkungannya (masyarakat/teman sebaya) tidak memberikan dukungan dalam bentuk pendidikan atau pengaruh yang positif terhadap jiwa tersebut. Sehingga dengan demikian potensi hanya tinggal sebuah potensi saja yang tidak bisa teraktualisasi karena tidak pernah diberi stimulus yang sesuai dengan potensi tersebut. ${ }^{13}$

\section{Perbedaan antara Nafs (Jiwa) dengan Roh}

Nafs dalam khazanah Islam memiliki banyak pengertian. Nafs dapat berarti jiwa (soul), nyawa, ruh, kondisi yang berdaya syahwat dan ghadhab, kepribadian, dan substansi psikofisik manusia. ${ }^{14}$ Pada substansi nafs ini komponen jasad dan ruh

${ }^{11}$ Noer Rohmah. Pengantar Psikologi Agama., op., cit., hlm., 09

${ }^{12}$ Al-Hadis.

${ }^{13}$ Noer Rohmah. Pengantar Psikologi Agama., op., cit., hlm., 310

${ }^{14}$ Ahmad Mubarak. Jiwa dalam Al-Quran, Solusi Krisis Kerohanian Manusia Modern. : 2000) 
bergabung. Nafs memiliki natur gabungan antara natur jasad dan ruh. Nafs adalah potensi jasadi - ruhani (psikofisik) manusia secara inhern telah ada sejak manusia siap menerimanya. Potensi ini terikat dengan hukum yang bersifat jasadi - ruhani. ${ }^{15}$ Semua potensi yang terdapat pada nafs bersifat potensial, tetapi dapat aktual jika manusia mengupayakan, dan aktualisasi nafs membentuk kepribadian, yang perkembangannya dipengaruhi oleh faktor internal dan eksternal.

Adapun ruh merupakan substansi psikis manusia yang menjadi esensi kehidupannya. Sebagian ahli menyebut ruh sebagai badan halus (jism lathif). Ruh adalah substansi yang memiliki natur tersendiri. ${ }^{16}$ Menurut Ibnu Sina, ruh adalah kesempurnaan awal jisim alami manusia yang tinggi yang memiliki kehidupan dengan daya. ${ }^{17}$ Sedang bagi al Farabi, ruh berasal dari alam perintah (amar) yang mempunyai sifat berbeda dengan jasad. Hal itu dikarenakan ia dari Allah, kendatipun ia tidak sama dengan dzatNya. Sedang menurut al Ghazali ruh ini merupakan lathifah (sesuatu yang halus) yang bersifat ruhani. Ia dapat berpikir, mengingat, mengetahui dan sebagainya. Ia juga sebagai penggerak bagi keberadaan jasad manusia, sifatnya gaib. Selanjutnya Ibnu Rusyd memandang ruh sebagai citra kesempurnaan awal bagi jasad alami yang organik. Kesempurnaan awal ini karena ruh dapat dibedakan dengan kesempurnaan yang lain yang merupakan pelengkap dirinya, seperti yang terdapat pada berbagai perbuatan, sedangkan disebut organik karena ruh menunjukkan jasad yang terdiri dari organ-organ. ${ }^{18}$

Fitrah ruh multi dimensi yang tidak dibatasi ruang dan waktu. Ruh dapat keluar masuk ke dalam tubuh manusia. Ruh

${ }^{15}$ Sayid Husein Nasr, Terj.B. Abdullah Hadi. Judul aslinya. Living Sufism Jakarta : Pustaka firdaus. 1994., hlm., 18).

${ }^{16}$ Agus Mustofa. Menyelam ke Samudera jiwa dan Ruh. Surabaya : PADMA Press : 2005)

${ }^{17}$ Noer Rohmah. Pengantar Psikologi Agama., op., cit., hlm., 313

${ }_{18}$ Ma'an Zidayat. Al-Mausyu'at Al-falsafiyah Al-'Arabiyah. Arab : Inma Al-'Arabi., hlm., 1986:465 
hidup sebelum tubuh manusia ada. Hal ini sebagaimana yang dijelaskan Allah swt dalam al-Quran (QS. Al-A'raf :172,
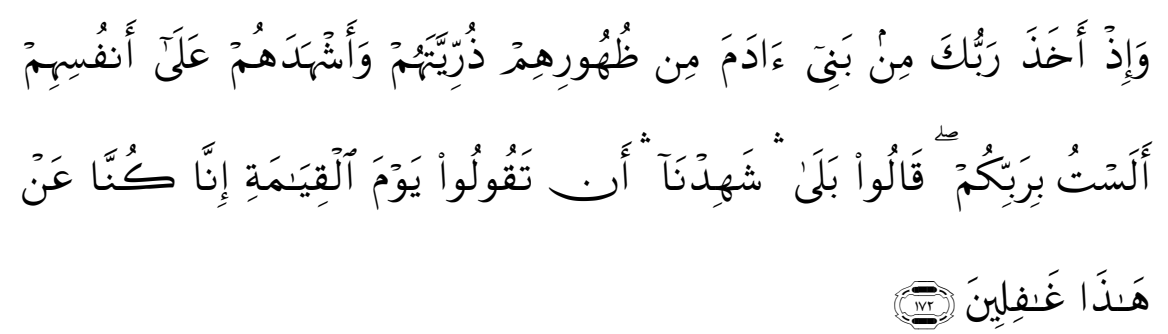

Artinya: Dan (ingatlah), ketika Tuhanmu mengeluarkan keturunan anak-anak Adam dari sulbi mereka dan Allah mengambil kesaksian terhadap jiwa mereka (seraya berfirman): "Bukankah Aku Ini Tuhanmu?" mereka menjawab: "Betul (Engkau Tuban kami), kami menjadi saksi". (Kami lakukan yang demikian itu) agar di hari kiamat kamu tidak mengatakan: "Sesungguhnya kami (Bani Adam) adalah orang-orang yang lengah terhadap Ini (keesaan Tuhan)", ${ }^{19}$

Kematian tubuh bukan berarti kematian ruh. Ruh masuk ke dalam tubuh manusia ketika tubuh tersebut siap menerimanya. Menurut hadits Nabi, bahwa kesiapan itu ketika manusia berusia 4 bulan dalam kandungan. (al-Bukhori). Pada saat inilah ruh berubah nama menjadi an-nafs (gabungan antara ruh dan jasad). ${ }^{20}$

Pada dasarnya pembahasan tentang ruh dibagi menjadi dua bagian; Pertama, ruh yang berhubungan dengan zatnya sendiri yang disebut dengan al-munazzalah, yang kedua yaitu ruh yang berhubungan dengan badan jasmani atau disebut dengan algharizah atau nafsaniyah. Ruh al-munazzalah berkaitan dengan esensi asli ruh yang diturun-kan atau diberikan secara langsung dari Allah SWT. Kepada manusia. Ruh ini esensinya tidak berubah, sebab jika berubah berarti berubah pula eksistensi manusia. $^{21}$

${ }^{19}$ (QS. Al-A'raf: 172

${ }^{20}$ Abdul Mujib. Fitrah dan Kepribadian Islam. Jakarta : Darul Falah., 2002., hlm., 43.

${ }^{21}$ Noer Rohmah. Pengantar Psikologi Agama., op., cit.,m hlm., 314 
Ruh al munazzalah ini diciptakan di alam ruh ('alam alarwah) atau di alam perjanjian. Karena itu ruh ini ada sebelum tubuh manusia ada, sehingga sifatnya sangat gaib yang adanya hanya diketahui melalui informasi wahyu. Fungsinya berguna untuk memberikan motivasi dan menjadikan dinamisasi tingkah lakunya. Ruh ini membimbing kehidupan spiritual nafsani manusia. Wujud ruh al-munazzalah adalah al-amanah. Amanah adalah titipan atau kepercayaan Allah yang dibebankan (taklif) kepada manusia untuk menjadi hamba dan khalifah di muka bumi. Tugas seorang hamba adalah menyembah dan berbakti kepada penciptanya, sebagaimana dalam Qur'an surat al-Dzariyah ayat 56:

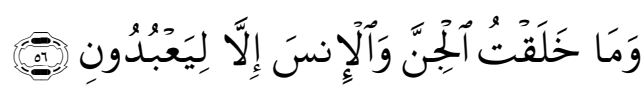

Artinya: "Dan aku tidak menciptakan jin dan manusia melainkan supaya mereka mengabdi kepada-Ku.". ${ }^{22}$

Dari ayat tersebut di atas jelas bahwa tugas seorang hamba adalah mengabdi atau beribadah kepada Tuhan semata, sebab ketika di alam arwah manusia telah berjanji bahwa Allah adalah Tuhannya, sebagaimana tersebut dalam al-Qur'an surat al-A'raf: 172: sebagaimana dijelaskan di atas.

Substansi nafs memiliki potensi gharizah (instink, naluri, tabiat, perangai, kejadian laten, ciptaan dan sifat bawaan). Jika potensi gharizah ini dikaitkan dengan substansi jasad dan ruh maka dapat dibagi menjadi tiga bagian yaitu; (1) al- qolb yang berhubungan dengan rasa atau emosi; (2) al 'aql yang berhubungan dengan cipta atau kognisi; dan (3) daya al-nafs yang berhubungan dengan karsa atau konasi. Ketiga potensi tersebut merupakan subsistem nafs manusia yang dapat membentuk kepribadian. ${ }^{23}$

\section{Tazkiyat Al-Nafs dalam Al-Quran}

Penyucian jiwa (tadzkiyat al-nafs) sesunggulinya merupakan tawaran Allah Yang Mahakuasa kepada umat manusia. Meraih tawaran itu atau menolaknya, merupakan hak penuh manusia.

22 al-Dzariyah : 56:

${ }^{23}$ Noer Rohmah. Pengantar Psikologi Agama., op., cit., hlm., 321 
Yang beruntung atau merugi, bukanlah Allah tapi manusia itu sendiri. Seorang Muslim yang menerima tawaran Allah, dan berusaha melaksanakannya, adalah manusia yang beruntung. Dia akan berusaha sedapat mungkin melaksanakan perintah-perintah Allah dan menjauhi larangan-larangan-Nya. Yang dimaksudkan dengan perintah dan larangan-Nya, bukan saja perintah dalam ibadah formal, seperti salat, zakat, puasa, dan haji, tapi juga segala sesuatu yang dianjurkan-Nya seperti melaksanakan budi-pekerti (akhlak) yang terpuji, sebagaimana telah dicontohkan Nabi Muhammad saw.. Usaha itu yaitu usaha membersihkan diri akan menghasilkan kedamaian, kebahagiaan, dan kesejukan di dalam hati. Pembersihan diri sangat erat hubungannya dengan pendekatan diri. Allah tak bisa didekati oleh orang yang tidak suci, karena Allah adalah Yang Mahasuci. Nabi Muhammad saw., para sahabat, para tabi'in, para hamba Allah yang saleh, senantiasa melaksanakan pendekatan diri kepada Allah itu. Penyucian diri merupakan usaha mendapatkan rida Allah Swt. ${ }^{24}$

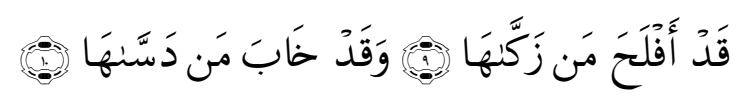

Artinya: Sesungguhnya beruntunglah orang yang mensucikan jiwa itu, Dan Sesungguhnya merugilah orang yang mengotorinya. ${ }^{25}$

Pada zaman Nabi, orang-orang yang senantiasa menyucikan dirinya itu, belum diberi julukan. Baru kemudian orang-orang seperti itu disebut "sufi," karena mereka biasanya berpakaian sangat sederhana terbuat dari wol (siif) yang sangat kasar. Menurut para ahli sejarah kesufian, pada zaman dinasti Abbasiyah berkuasa di Baghdad, banyak yang tidak menyukai para khalifah Abbasiyah itu, karena mereka sangat lalim. Rakyat diperlakukan tidak semestinya. Rakyat tidak puas dan mencari kepuasan di bidang rohani. Banyak di antara mereka yang lari menjauhkan diri dari keduniaan dan menjadi zahid (orang yang hidup zuhud). Di

${ }^{24}$ M. Yudhie Haryono (Ed). Al-Quran Kritis. op., cit., hlm., 147

25 (Q.S. 9-10) 
samping mereka menjauhkan diri dari keduniaan, mereka berusaha keras memerangi nafsu-nafsu yang tidak baik dalam diri mereka. Mereka sadar, bahwa tidak ada manusia yang tidak berbuat kekhilafan.

Langkah awal menyucikan diri itu, ialah bertobat, di samping menjalankan kesabaran, kemudian menanamkan ke dalam diri sifat berserah diri (tawakal) kepada Allah. Langkah awal tersebut kemudian ditingkatkan menjadi rela menerima segala putusan Allah, enak ataupun tidak, senang ataupun tidak, karena ini semua didasarkan kepada ke-Maha-Kasih-an dan ke-Maha-Sayang-an Allah kepada hamba-Nya. ${ }^{26}$

Zahid-zahid pada masa Abbasiyah itu, antara lain: Suryan alTsauri, Abu Hasyim dan Jabir ibn Hasyim di Kufah; di Basrah: Hasan Brasri dan Rabiah al-Adawiyah. Cara hidup zuhud ini kemudian menyebar ke Parsi dengan Ibrahim ibn Adhamnya, dan di Madinah, Ja'far al-Sadiq. Zahid-zahid yang disebutkan di atas, adalah sufi yang sudah mencapai jenjang tinggi di dalam usaha pendekatan diri kepada Allah.

Gambaran utuh seorang sufi, adalah mereka tak pcrnah melupakan zikir dan salat. Hidupnya dihiasi dengan akhlak yang mulia, jauh dari sifat riya dan sombong. Ilmu yang dimilikinya, disebarkan dengan mengajarkannya kepada mereka yang mau belajar dan waktunya selalu diisi dengan ibadah, semata-mata mencari rida-Nya. Sebagai contoh, saat-saat akhir hidup alJunaid - digambarkan oleh murid-muridnya yang menjaganyatetap menjalankan ibadahnya, sungguh pun sakitnya telah parah. Pada saat beliau meng-hembuskan nafasnya yang terakhir, AlQuran ada di tangannya yang terkulai, menunjukkan bahwa beliau habis membacanya.

Makin lama makin banyak orang tertarik hidup zuhud, karena mereka tidak puas dengan hidup duniawi. Pada zaman Abbasiyah, mereka meng-amalkannya dengan sembunyisembunyi, kemudian mereka berkumpul di ruang tempat mendidik calon sufi, yang disebut zawiyah. Di sini mereka melakukan

\footnotetext{
${ }^{26}$ M. Yudhie Haryono (Ed). Al-Quran Kritis. op., cit., hlm., 148
} 
latihan-latihan yang diajarkan guru mereka. Segala bimbingan guru itu dinamakan tarekat. Lama kelamaan tarekat juga berarti perguruan, umpamanya tarekat Qadariyah yang menjalankan ajaran Syeikh Abdul Qadir al-Jailaini. Ada tarekat Naqsyabandiyah, ada Syatariah, Khalwatiyah, dan banyak lagi tarekat. $^{27}$

Tarekat dipimpin seorang mursyid. Mursyid itu dianggap sesepuh dan ahli di bidang tasawuf (ilmu yang diselami dan dihayati para sufi). Mursyid juga disebut syeifeh tarekat. Syeikh tarekat bisa merupakan orang yang menemukan metode dan ajaran pendekatan diri kepada Allah, bisa juga hanya merupakan orang yang meneruskan metode yang didapatnya dari gurunya. Mursyid macam kedua ini, biasanya seorang yang oleh gurunya sudah dianggap orang yang mampu menyampaikan ajarannya dan melatih para muridnya. Mursyid seperti ini mempunyai hak mengajar, karena telah menerima ijazah dari gurunya.

Jadi murid yang mendapat ijazah dari tarekat Qadariyah, akan mengajarkan metode dan ajaran tarekat Qadariyah pula. Tapi adakalanya, dua tarekat diajarkan di perguruan yang sama. Tarekat semacam itu, umpamanya tarekat Qadariyah Naqsyabandiyah di Suryalaya, Tasikmalaya, Jawa Barat.

Berhubung tujuan tiap tarekat itu sama, yaitu mendekatkan diri (taqarrub) kepada Allah, maka tidak menjadi halangan, kalau muryid ingin mengajarkan metode dan ajaran tarekat yang lain yang juga dianggapnya cocok bagi murid-muridnya. Salah satu metode yang khusus di dalam pendekatan diri kepada Allah, ialah dzikir (mengingat Allah dalam hati atau dengan mengucapkanNya), berdasarkan perintah-Nya dalam Alquran dan berdasarkan contoh-contoh yang diberikan Nabi Muhammad). Ada bermacammacam zikir, misalnya, takbir (Allah Akbar), ada juga zikir dengan menyebut astna (nama-nama) Allah. Zikir tertinggi, adalah salat, karena salat mencakup segala-galanya, lahir maupun batin. ${ }^{28}$ Kita lihat ayat Alquran,

${ }^{27}$ Ibid., hlm., 149.

${ }^{28}$ Ibid., hlm., 150. 


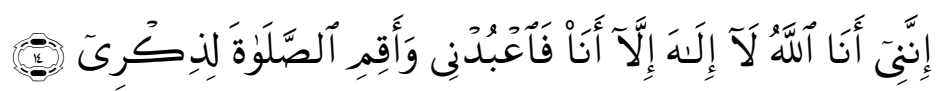

Artinya: Sesungguhnya Aku Ini adalah Allah, tidak ada Tuhan (yang hak) selain aku, Maka sembahlah Aku dan Dirikanlah shalat untuk mengingat Aku. ${ }^{29}$

Salat itu merupakan anugerah besar Yang Maha Pencipta, karena dengan melakukan salat wajib 5 kali sehari semalam, berarti kita telah menghubungkan diri kita dengan Allah. Dianjurkan juga oleh Allah, untuk melaksanakan salat-salat sunnah, yaitu supaya kita lebih banyak lagi ingat kepada Yang Maha Kuasa itu. Tentang zikir kepada Allah, dikatakan dalam Alquran,

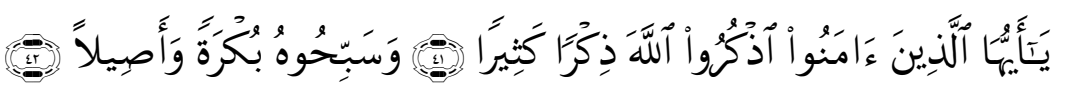

Artinya: Hai orang-orang yang beriman, berzdikirlah (dengan menyebut nama) Allah, zikir yang sebanyak-banyaknya. Dan bertasbihlah kepada-Nya diwaktu pagi dan petang. ${ }^{30}$

Zikir dipandang sebagai iman yang terus-menerus (tanpa henti) yang dilakukan setiap saat. Pada prinsipnya, zikir harus dilaksanakan berdasarkan cara dan sopan-santun ( $a d a b)$ yang telah ditentukan Allah dalam Alquran dan juga telah dicontohkan Rasulullah. Zikir harus dilaksanakan dengan sepenuh hati, dengan rasa cinta kepada Allah, dengan merendahkan diri dan dengan suara perlahan-lahan (tidak keras). Allah Swt. berfirman,

Artinya: "Dan, sebutlah (nama) Tiihan-mu dalam hatimu dengan merendahkan diri dan rasa takiit, dan dengan tidak mengeraskan suara di waktu pagi dan petang, dan janganlah kamu tertnasuk orang-orang yang lalai". ${ }^{31}$

Keutamaan dan keistimewaan zikir itu sangat besar dan jika kita melaksanakannya dengan baik, akan membuahkan keberuntungan dan kebahagiaan, berdasarkan firman Allah,

${ }^{29}$ (Q.S. Thaha: 14).

30 (Q.S. al-Ahzab: 41-42).

31 (Q.S. al-Anfal: 205) 
Artinya: "Hendaklah kamu berzikir kepada Allah sebanyakbanyak- nya, agar kamu babagia". ${ }^{32}$

Sikap lalai zikir kepada Allah dapat mengakibalkan seseorang merugi besar, memudarkan keimanan, memperkuat tarikan hawa-nafsunya, dan menjerumuskannya kepada kemaksiatan. Maka kita hendaknya jangan lupa mengingat Allah, supaya kita senantiasa diberi petunjuk (hidayah). Allah berfirman,

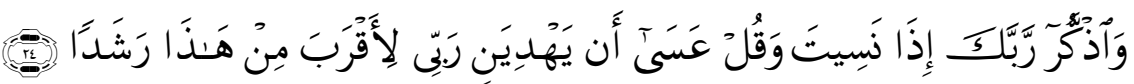

Artinya: Dan ingatlah kepada Tuhanmu jika kamu lupa dan Katakanlah: "Mudah-mudahan Tuhanku akan memberiku petunjuk kepada yang lebih dekat kebenarannya dari pada ini". ${ }^{33}$

Zikir dapat mengingatkan kita supaya meluruskan pikiran, jangan menyimpang dari jalan yang telah Allah tunjukkan. Kita hendaknya senantiasa yakin. Keyakinan yang bisa dijalankan dengan dua cara; Pertama, yakin akan kekuasaan Allah yang tak terhingga yang tergambar dalam ciptaan-Nya berupa langit dan bumi beserta segala isinya. Kediia, yakin bahwa adanya diri kita di dunia ini tidaklah sia-sia, sesuai dengan firman Allah, bahwa jin dan manusia diciptakan, semata-mata untuk berbakti kepada Allah (Q.S. al-Zariat: 56). Jadi jelas bahwa kita ini tidak diciptakan siasia. Dengan demikian, kita pun jangan menyia-nyiakan hidup kita ini. Ketiga, yakin bahwa manusia itu pasti mati. Pada suatu saat pasti akan dipanggil pulang

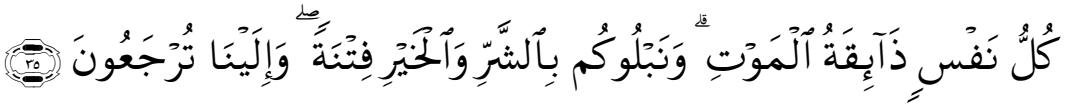

Artinya: Tiap-tiap yang berjiwa akan merasakan mati. kami akan menguji kamu dengan keburukan dan kebaikan sebagai cobaan (yang sebenar-benarnya). dan Hanya kepada kamilah kamu dikembalikan. ${ }^{34}$

\footnotetext{
${ }^{32}$ M. Yudhie Haryono (Ed). Al-Quran Kritis. op., cit., hlm., 151

${ }^{33}$ (Q.S. al-Kahfi: 24).

${ }^{34}$ (Q.S. al-Anbiya: 35).
} 
Ayat di atas menjelaskan bahwa setiap yang bernyawa pasti akan mati, dan kembali kea lam baka. Dari sini kitalah yang akan menentukan jalan kembali dan tempat kembali kitaApakah kita kelak akan masuk rumah yang telah dipersiapkan dengan baik ataukah kita kelak akan masuk ke gubuk di bawah jembatan, itu merupakan hasil perbuatan manusia itu sendiri. Keempat, yakin dan banyak lagi yakin, yakin, dan yakin. Renungkan pula isi surat al-Rahman, di mana, Allah mengulang-mengulang, ${ }^{35}$ "Maka nikmat Tuhan kamu manakah yang kamu dustakan?"

Mengingat setiap nafs akan mati, maka dari itu, sebelum ajal menjemput nyawa atau ruh kita, kita harus mempersiapkan diri agar jiwa kita bisa kemabali kea lam baka dengan tenang dan mendapatkan tempat yang baik di sisi tuhan.

Perbuatan menyadarkan dan meyakinkan diri seperti dikatakan di atas, disebut tafakur (merenung), bukan melamun. Hati dan otak bekerjasama. Tafakur akan mengantarkan kita kepada iman yang lebih mantap dan tangguh, tidak mudah kena senggol. Dan, hendaknya kita banyak bersyukur atas segala limpahan rahmat-Nya. Perhatikan ayat-ayat Al-Quran ini,
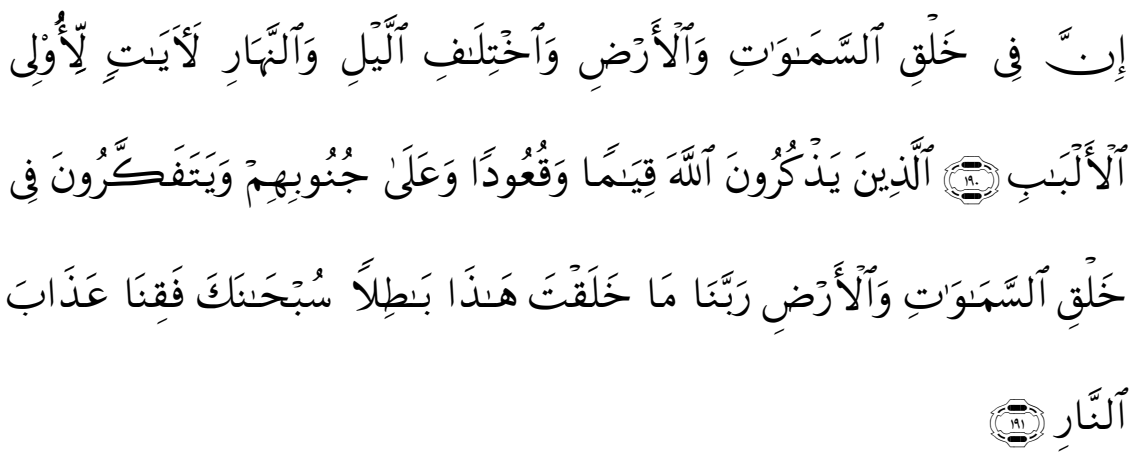

Artinya: Sesungguhnya dalam penciptaan langit dan bumi, dan silih bergantinya malam dan siang terdapat tanda-tanda bagi orang-orang yang berakal, (yaitu) orang-orang yang mengingat Allah sambil berdiri atau duduk atau dalam keadan berbaring dan mereka memikirkan

${ }^{35}$ M. Yudhie Haryono (Ed). Al-Quran Kritis. op., cit., hlm., 132 
tentang penciptaan langit dan bumi (seraya berkata): "Ya Tuhan kami, tiadalah Engkau menciptakan Ini dengan sia-sia, Maha Suci Engkau, Maka peliharalah kami dari siksa neraka. ${ }^{36}$

Disinilah pentingnya membersihkan diri (tazkiyat Al-Nafsi). Untuk membersihkan diri banyak caranya. Diantaranya adalah dengan cara berzikir yakni selalu ingat kepada Allah swt. Zikir akan menjadikan makin dekatnya hamba kepada Allah. Barang siapa sering lupa kepada Allah, maka Allah pun akan menjauhkannya dari rahmat-Nya. Sebaliknya Allah pun akan selalu ingat kepada kita, kalau kita pun selalu ingat kepada-Nya. Firman-Nya,

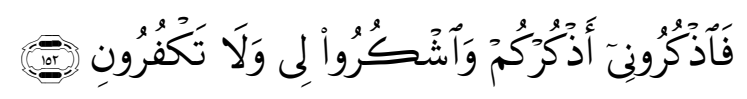

Artinya: Karena itu, ingatlah kamu kepada-Ku niscaya Aku ingat (pula) kepadamu, ${ }^{37}$ dan bersyukurlah kepada-Ku, dan janganlah kamu mengingkari (nikmat)-Ku. ${ }^{38}$

Berdasarkan suatu hadis yang diriwayatkan Ibn Majah, $A k u$ beserta hamba-Ku selama ia sebut Aku dan bergerak kedua bibirnya dalam menyebut nama-Ku. Zikir memberikan pengaruh yang sangat positif pada si ahli zikir sesuai dengan apa yang difirmankan Allah. ${ }^{39}$

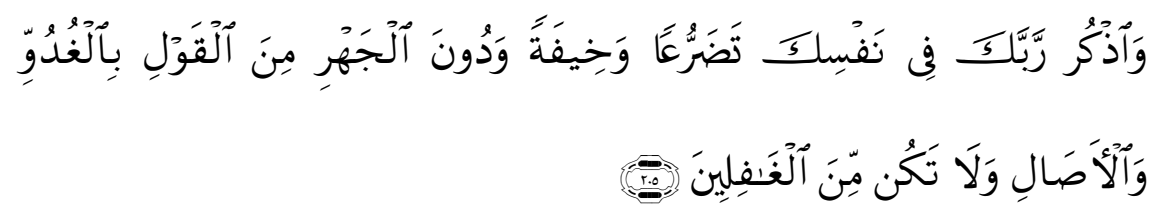

Artinya: Dan sebutlah (nama) Tuhannmu dalam hatimu dengan merendahkan diri dan rasa takut, dan dengan tidak

${ }^{36}$ (Q.S. Ali 'Imran: 190-191)

${ }^{37}$ Maksudnya: Aku limpahkan rahmat dan ampunan-Ku kepadamu.

${ }^{38}$ QS. Al-Baqarah : 153

${ }^{39}$ Q.S. al-Araf: 205). 
mengeraskan suara, di waktu pagi dan petang, dan janganlah kamu termasuk orang-orang yang lalai. ${ }^{40}$

bahwa ahli zikir akan merasakan suatu rasa nikmat yang sangat sukar diungkapkan dengan kata-kata karena bahasa terlalu miskin untuk mengungkapkannya. Ketenangan dan ketenteraman jiwa (sakinah) memenuhi seluruh rongga dada. Badan akan terasa ringan sekali, seolah-olah tidak berbadan. Pikiran-pikiran kacau sirna entah ke mana, padahal tadinya sangat menekan sehingga terasa sesak. Pengalaman spiritual seperti ini biasa dirasakan para ahli zikir. Ini adalah kondisi manusia yang tidak mungkin diterangkan dengan akal semata-mata. ${ }^{41}$ Ini adalah rahmat Allah Swt.. Janji Allah, swt.

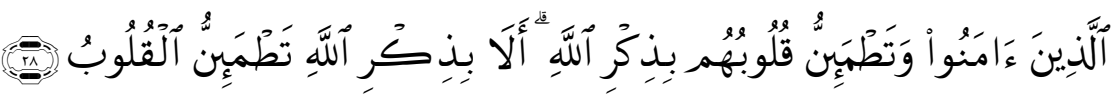

Artinya: (yaitu) orang-orang yang beriman dan hati mereka manjadi tenteram dengan mengingat Allah. Ingatlah, Hanya dengan mengingati Allah-lah hati menjadi tenteram. ${ }^{42}$

Terkait dengan masalah zikir, Rasulullah menjelaskan, bahwa di akherat nanti orang yang akan dinaungi Allah di hari tiada naungan, kecuali naungan-Nya, ialah orang-orang yang berzikir kepada Allah di tempat yang sunyi sambil mencucurkan air matanya. Cucuran air mata dari seorang ahli zikir, merupakan manifestasi dari khusuk-nya kepada Allah sebagai suatu kesadaran batin yang sangat tinggi nilainya.

Penjelasan Rasulallah saw di atas menunjukkan betapa istimewanya para pelaku zikir sampai-sampai hanya merekalah yang akan mendapat naungan di hari taka da lagi naungan selain naungan dar Allah swt. Karena itu sungguh berbahagialah orang yang selalu berzikir (membersihkan jiwa dengan membaca zikir,

${ }^{40}$ Q.S. al-Araf: 205)

${ }^{41}$ M. Yudhie Haryono (Ed). Al-Quran Kritis., op., cit., hlm., 153

${ }^{42}$ (QS. al-Ra'd: 28). 
dan sungguh akan merugilah orang yang lalai dari mengingat allah swt.

Dengan demikian, maka sungguh barangsiapa bisa mancapai tingkat kesadaran batin seperti itu adalah manusia yang sangat beruntung, dan akan merasakan ketenangan jiwa (sakinah) dan kenikmatan spiritual (kelezatan nikmat). Apa sesungguhnya yang menjadikan jiwa bisa merasakan ketenangan dalam keadaan zikir? Dalam keadaan berzikir, si ahli zikir tidak ingat kepada yang lainlain kecuali kepada Allah. Segala perhatiannya, pikirannya, berserah dirinya hanya ditujukan kepada Yang Maha Pengasih. ${ }^{43}$

Bagaimana batin orang yang sedang berzikir dalam upayanya mencari hubungan dengan Allah? Mari kita perhatikan firman Allah,

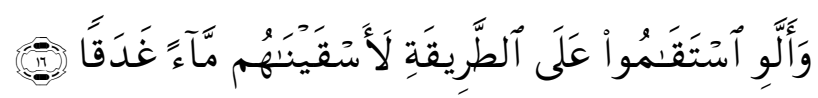

Artinya: Dan bahwasanya: Jikalau mereka tetap berjalan lurus di atas jalan itu (agama Islam), benar-benar kami akan memberi minum kepada mereka air yang segar (rezki yang banyak $)^{44}$

Orang yang sedang menempuh jalan mendekatkan diri kepada Allah dan berusaha supaya istiqamah dalam usahanya itu, pada akhimya akan menuju ke pengenalan dan perasaan adanya Allah. Dalam keadaaan seperti ini, dia akan melihat Allah dengan mata batinnya (ain al-basyirah).

Pernah Ali ibn Abi Thalib bertanya kepada Rasulullah, Manakah jalan (tarekat) yang sedekat-dekatnya mencapai Allah?" Dijawab oleh Nabi: "Tidak lain daripada zikir kepada Allah." Zikir tadi, senantiasa harus ditingkatkan. Tanjakan-tanjakan batin inilah yang berat, tapi bagi orang yang sudah tinggi kualitas berserah dirinya (tawakalnya) tanjakan-tanjakan batin tersebut dapat dilaluinya dengan mudah.

${ }^{43}$ M. Yudhie Haryono (Ed). Al-Quran Kritis. Q.S. al-Araf: 205)., hlm., 154

44 (Q.S. al-Jin: 16). 
Orang yang dalam keadaan zikir, tidak konsentrasi, tapi kontemplasi dengan maksud mengenal Allah. Sebuah hadis berbunyi, Barangsiapa mengenal dirinya, maka ia mengenal Tuhannya.

Hadis di atas sungguh luar biasa. Bahwa orang yang telah mengenal dirinya sendiri, maka ia pun akan dapat mengenal tuhannya. Oleh sebab itu, adalah wajib bagi setiap individu untuk selalu berzikir mengingat Allah swt, dan selalu menghadapkan hati kita hanya kepada Allah. Karena itu, kita sebagai hamba Allah swt harus selalu yakin bahwa di dalam menyembah Allah (dalam salat, umpamanya) kita melihat Allah, berdasarkan sebuah Hadis, Sembahlah Tubanmu seakan-akan engkau melihat-Nya, jika engkau tidak melihat-Nya, yakinlah bahwa Allah sesungguhnya melihatmu. $^{45}$

Dianjurkan supaya kita berusaha kusuk di dalam salat. Kita harus sadar bahwa segala amal-ibadah itu semata-mata karena Allah. Kita harus yakin bahwa kita sedang berhadapan dengan Allah dan berkomunikasi dengan-Nya. Pada tingkatan batin seperti ini, Allah berkata, "Akulah Allah." Kehadiran hati dari orang yang sedang kusuk tadi berkata, "Engkaulah Allah." Lalu Allah berkata pula, "Salatlah untuk mengingat Aku."

Menurut orang sufi, orang yang salat, tapi sama sekali tidak ada kehadiran hatinya kepada Allah, salatnya tidak sah. Imam alGhazali mengatakan, bahwa pada orang yang sedang kusuk, terbukalah "cahaya yang gaib" di dalam hatinya. Ketika orang mengira bahwa al-Ghazali telah mencapai derajat yang begitu dekat kepada Allah, lalu bertanya tentang pengalaman itu, beliau menjawab, "Barangsiapa mengalaminya, hanya akan dapat mengatakan bahwa hal itu merupakan suatu hal yang tidak dapat diterangkan, indah, utama, dan janganlah bertanya lagi." Beliau melanjutkan, bahwa hanya hati yang telah bersih dan murni itulah yang dapat melihat Allah.

Untuk mencapai tingkatan tinggi seperti dicapai al-Ghazali, para sufi rida melakukan latihan-latihan jiwa yang berat untuk

${ }^{45}$ M. Yudhie Haryono (Ed). Al-Quran Kritis. Q.S. al-Araf: 205)., hlm., 155 
mengosongkan diri dari sifat-sifat tercela (takhalli) dan mengisinya dengan sifat-sifat terpuji (tahalli) serta rela memutuskan segala hubungan yang dapat merugikan kesucian dirinya, serta mempersiapkan dirinya untuk menerima pancaran Nur Ilahi (tajalli). Semua usaha tersebut jika dilakukan dengan segala kesungguhan hati, biasanya berhasil. Menurut al-Ghazali, ini disebabkan karena Allah adalah Maha Cahaya bagi segala ciptaanNya. Karena Dia adalah Sumber Cahaya dan Ilmu. Apabila Allah telah menembus hati hamba-Nya dengan Nur, maka pastilah Dia akan melimpahkan rahmat-Nya. ${ }^{46}$

Pada tingkat ini, hati hamba-Nya bercahaya terangbenderang, yang selama itu tertutup (terhijab) pun terkuak selebarlebarnya. Pada tingkat ini, seorang sufi mengalami fana fi-'llah (lenyap sifat dirinya dan tenggelam di dalam kehadiran Allah). Keadaan fana ini tidak merupakan akhir dari usaha batin seorang sufi. Kata al-Ghazali, setelah sampai pada tingkat ini, seorang sufi masih harus naik lagi ke beberapa tingkat yang tidak terjangkau kata-kata. Ini disebut tajalli (memperoleh kenyataan Allah). Seperti dikatakan Junaid al-Baghdadi, "Hatimu itu rumah Allah. Jangan biarkan yang lain duduk di dalamnya, kecuali Allah. Kamu tidak akan mencapai baqa (kekal dengan Allah) sebelum melalui fana." Seorang sufi yang sampai di tingkat fana, pasti sudah melewati tingkat penghancuran diri sendiri. Diri sendiri tidak dihitung lagi (egoless). Makin tinggi hidup kerohaniannya, seorang sufi akan begitu dekat kepada Yang Mahasuci, sehingga ia merasa seolah-olah bersatu dengan Allah. Tingkat ini disebut ittihad (unioMystica). Penghancuran diri itu senantiasa diikuti oleh baqa (kekal, tetap). Kalau seorang sufi sudah dapat menghancurkan dirinya (egoless tadi), maka apa pun hilang, termasuk perasaan dan kesadaran tentang adanya tubuh kasar dirinya (bodiless). Sebenarnya dirinya tetap ada, makhluk-makhluk di sekelilingnya pun tetap ada, hanya saja, ia sendiri yang tidak lagi menyadari semua itu. Salah satu Hadis juga menceritakan keadaan Nabi kita pada suatu saat. Dia tak mengenali istrinya Aisyah dengan

\footnotetext{
${ }^{46}$ M. Yudhie Haryono (Ed). Al-Quran Kritis., op., cit., hlm., 156
} 
mengajukan pertanyaan: "Aisyah mana?" Dijawab oleh Aisyah: "Anak Abu Bakar," Nabi bertanya kembali" "Abu Bakar mana?". ${ }^{47}$

Hubungan yang telah begitu dekat dengan Allah, yaitu di mana seorang sufi merasa dirinya telah bersatu dengan Allah dan berbicara dengan nama Allah, dalam sejarah kesufian, merupakan kejadian-kejadian yang tidak aneh. Kita pernah mendengar nama al-Hallaj (Husein ibn Mansur al-Hallaj) yang misalnya terkenal dengan ucapannya Ana 'l-Haqq (bahwa Aku adalah Allah). Kita juga bisa menyinggung sedikit tentang sufi Abu Yazid al-Bustami. Pernah dalam keadaan fana, beliau berkata, "Tiada Tuhan melainkan Aku. Sembahlah aku, maha sucilah aku. Alangkah besar kekuasaanku." Apabila ia telah kembali sadar, murid-muridnya bertanya, "Mengapa tuan guru berkata demikian?" Beliau menjawab: "Aku tidak tahu apa yang aku katakan."

Abu Yazid menceritakan apa yang telah dicapainya dalam menyelami hidup rohani, antara lain, "Apabila Allah melepaskan dan memisahkan aku dari semua makhluk dan dikarunia-Nya aku dengan sinar-Nya dan diberitahu-Nya aku akan rahasia-Nya, maka terlihatlah olehku Allah itu dengan mata hatiku. Apabila aku bandingkan Nur Ilahi itu dengan diriku, maka terasa hina dan tidak ada nilainya lagi aku ini. Di hadapan kesucian-Nya, aku adalah tidak suci. Apabila Allah mem-fana-kan aku dan membawa aku baqa dengan-Nya dan membuka hijab yang menghal angi aku dengan Dia, maka aku pun dapat melihat-Nya, dan ketika itu hancur leburlah panca-inderaku dan tidak dapat berkata apa-apa. Hijab itu tersingkap ${ }^{48}$ dan aku ada dalam keadaan yang demikian beberapa lama tanpa pertolongan pancaindera sedikit pun. Kemudian Allah karuniakan mata ketuhanan dan telinga ketuhanan, dan aku dapati segala-galanya adalah di dalam Dia juga." Inilah sesungguhnya inti ajaran kesucian jiwa, suatu kesucian yang bisa didapatkan dari para sufi. ${ }^{49}$

${ }^{47}$ Ibid., hlm., 157-158.

${ }^{48}$ M. Yudhie Haryono (Ed). Al-Quran Kritis., op., cit., hlm., 158.

${ }^{49}$ Ibid., hlm., 159. 


\section{PENUTUP}

Permasalahan nafs atau jiwa atau ruh sangat menarik untuk dibahas. Namun demikian dari dulu hingga sekarang. Masalah ruh tetap saja menjadi misteri dan tak bisa diketahui bagaimana hakekatnya. Hal ini karena manusia hanya diberi pengetahuan tentang ruh sangat sedikit, sehingga akan sulit bahkan tidak mungkin bagaimanpun bagi manusia mengeatahui hakekat ruh. Berbagai macam percobaan dilakukan oleh para pakar untuk bisa mengetahui tentang ruh. Namun hingga kini taka da seorang pakar pun yang sanggup mengetahui apa hakekat ruh tersebut. maha benar allah yang telah berfirman. Dan tidaklah aku beri pengetahuan (ilmu ) tentang ruh kecuali hanya sedikit (sekali). Karena itu sampai kapanpun masalah ruh tetap akan menjadi misteri yang menarik untuk dibahas dan dibicarakan.

\section{DAFTAR PUSTAKA}

Abdul Mujib. 2002. Fitrah dan Kepribadian Islam. Jakarta : darul Falah. Agus Mustofa. 2005. Menyelam ke Samudera jiwa dan Ruh. Surabaya : PADMA Press.

Ahmad Mubarak. 2000. Jiwa dalam Al-Quran, Solusi Krisis Kerohanian Manusia Modern.

Al Ghazali. Abu Hamid. 1963. Fatihat Al-Ulum. Al-qahirat : MathbathShubaihi.

Noer Rohmah. 2013. Pengantar Psikologi Agama. Yogyakarta; Teras.

Hasan Langgulung. 1983. Manusia dan Pendidikan., Jakarta : Al-Husna.

M. Yudhie Haryono (Ed). 2003. Al-Quran Kritis. Jakarta : Nalar Bekerjasama dengan PT. Inti Media Cipta Nusantara.

Ma'an Zidayat. 1986. Al-Mausyu'at Al-falsafiyahAl-'Arabiyah. Arab : Inma Al-'Arabi.

Noer Rohmah. 2013. Pengantar Psikologi Agama. Yogyakarta; Teras. Sayid Husein Nasr. 1994. Terj.B. Abdullah Hadi. Judul aslinya. Living Sufism Jakarta : Pustaka firdaus. 